\title{
The role of a systematic analysis of building codes to support an assessment methodology for built heritage
}

\author{
C. Ornelas, J.M. Guedes \& I. Breda-Vázquez \\ Department of Civil Engineering, Faculty of Engineering, Porto, Portugal
}

\begin{abstract}
This paper analyses and compares codes and standards that support interventions on built heritage of three Southern European countries with similar cultural approaches, Italy, Spain and Portugal, and confronts these documents with technical expert opinion. This discussion recognizes the importance of incorporating flexible criteria on code application, but also that such criteria should be sustained by inventorying and cataloguing processes based on multidisciplinary assessment methodologies. When dealing with inhabited built heritage, this assessment methodology should not only be supported by safety and housing conditions criteria embedded in technical codes and standards and local guidelines oriented to the local characteristics of the constructions, but should also include the assessment of the needs and expectations of residents. This work is part of a vast study that includes and sustains the development of a multidisciplinary assessment methodology to be applied on built heritage.
\end{abstract}

\section{INTRODUCTION}

The rehabilitation of built heritage is an important issue within the current debate involving urban policies and building codes and/or technical regulations. In Portugal, most of the requirements of these codes and regulations are mainly directed to new buildings and its application to existing/old buildings is often constrained by pre-existing conditions that make it difficult to achieve performance levels identical to those of new buildings, with adequate intervention. This debate assumes particular relevancy when dealing with buildings with patrimonial value, i.e. buildings that demand the preserving of their particular (cultural, architectonic, material...) characteristics (Arcas-Abella et al., 2011, Fianchini and Fontana, 2010). Following this, several scholars are discussing the urgent need to adapt the legislation that regulates the construction sector to allow more flexible and proportional interventions on built heritage (García-Martinez et al., 2010, Tenorio Rios et al., 2012, Fianchini and Fontana, 2010, Casals-Tres et al., 2013, Alonso, 2010, Asensio and Martín, 2012).

Under these issues, this paper establishes a comprehensive and comparative study of codes and standards of three Southern European countries with comparable cultural approaches and architectonic and climatic conditions - Italy, Spain and Portugal -, concerning the protection, classification and intervention on built heritage. The study is complemented with the views of experts from governmental, municipal and academic institutions of the three countries on these subjects.

\section{A SYSTEMATIC ANALYSIS OF BUILDING CODES OF ITALY, SPAIN AND PORTUGAL}

This section gives an overview on the building codes, legislation and regulations of Italy, Spain and Portugal. Although being Southern European countries with similar culture approaches and architectonic and climatic conditions, these documents express different perspectives concerning classification and intervention on built heritage, reflecting the experiences and circumstances that affected over time the options of each country and that justify the actual criteria and procedures of the legislation. This analysis underlines the particularities of these documents and allows the identification of gaps in the Portuguese legislation.

\subsection{Criteria and procedures from building codes for intervention on built heritage}

The comparison of the building codes and regulations of the three selected countries points out the principal criteria and procedures involved in the assessment of the patrimonial value and safety and housing conditions. The following sections synthetize the outcomes of these regulations and present the main aspects that result from this comparison.

\subsubsection{Classification criteria}

The following paragraphs describe the regulation aspects related to built heritage classification, namely the main tools and criteria established by the codes for this item. 
Italy

In Italy, the national laws concerning protection and intervention on built heritage promote the creation of clear and homogenous criteria for its classification in all territorial scales. In particular, the code that supports the protection and valuation of cultural heritage (Italia, 2004), aiming to preserve the national community and territorial memory, defines heritage in two groups: cultural and landscape assets. The first group includes movable and immovable assets, while the second addresses protected areas with artistic, historic, archaeological, anthropological, landscape, archival and bibliographic value. Moreover, it underlines the importance of identifying elements and objects with particular patrimonial value within built heritage, and of establishing inventory and cataloguing processes; it presents measures for protection and conservation.

The code defines general and homogenous guidelines that are transported to regional laws which, on the other hand, present uniform and flexible criteria, allowing its adjustment at the municipal level. For example, there are standards for controlling the urban and building activity (Italia, 1985), with the objective to create unify databases and procedures to intervene in built heritage. These national control standards give the municipalities, with the approval of the regions, autonomy to create instruments to establish databases and measures on how to intervene in built heritage. These procedures have the participation of public and private agents that regulate the activity on built heritage.

In addition, with the same approach, the national regulation (Italia, 1978) defines general rules for the conservation and rehabilitation of urban and built heritage, referring technical criteria to evaluate residential buildings. These standards are adjusted and embedded in the municipal regulatory plans and define different intervention levels: ordinary maintenance, extraordinary maintenance, restoration, conservative rehabilitation, building restructuration; urban restructuration. These levels and measures are reflected in the urban regulations at the municipal level, being afterwards implemented in the general regulatory plans, which associate possible intervention levels to categories of buildings.

In this way, at the municipal level there is the establishment of clear criteria for classifying built heritage and to create degrees of intervention adjusted to different building categories, based on national and regional criteria. As an example, at the municipality of Padua, the general regulatory plans (Italia, 2012, Rumor and Gonzato, 1989) distinguish the typology and constructive technical systems and the state of conservation of the buildings through an inventory and cataloguing process, supported by cadastral maps, regional or municipal guidelines and photographic records, establishing classes of buildings.

\section{Spain}

In Spain, there is a national law concerning the protection of historic heritage (España, 1985) which establishes uniform criteria applicable to the entire country. It delimits a historic built heritage to an immovable asset with artistic, historic, paleontological, archaeological, ethnographic, scientific or technical interest. The law defines as important asset categories: monuments, historic ensembles, historic sites, immovable assets and surrounding areas.

Each region creates their own laws concerning specific criteria for classifying and cataloguing, not following a unified process. Asensio and Martín (2012) reveal that these procedures consent subjectivity in the allocation of levels of protection to buildings. Taking as example the Madrid Community, the regional law concerning historic heritage (España, 1998) follows general criteria from national laws, but the procedures of classification use specific criteria to define built heritage categories. They are put in practice by the regional administration in charge of the built heritage guardianship, in coordination with the municipal entities. Also, at municipal level there is regulation that sets measures of protection and interventions for the different levels of classification of built heritage, i.e. regulation that establishes the conditions of protection (España, 2011a) and rehabilitation of built heritage (España, 2011b). The first regulation defines three levels of buildings with patrimonial value: 1 - buildings with singular or integral value; 2 - buildings with structural or volumetric value; 3 - buildings with partial or environmental value. The second regulation establishes measures of protection and intervention for different levels of classification focused on existing buildings. This regulation appeals to the duty of maintenance and regular inspections, especially in buildings with more than 30 years, with the objective of verifying their state of conservation. In addition, the building code implements levels of rehabilitation: repair, renovation, extension, change of use.

It is important to highlight that there is a national law concerned with urban rehabilitation, regeneration and renewal (España, 2013). This law reinforces the urgency to intervene in the building stock, linking it to the economic and social aspects of the rehabilitation.

\section{Portugal}

In Portugal, the national law concerning the protection and classification of cultural heritage (Portugal, 2001) defines cultural heritage as an asset that testifies civilizational and cultural relevant values, 
especially with historic, archaeological, documental, artistic, ethnographic, scientific, technical, or social interest. According to this, cultural heritage reflects the values of memory, antiquity, authenticity, originality, rarity, singularity or exemplarity, and constitute part of the Portuguese identity and collective memory. It defines heritage categories as immovable assets, monuments, historic ensembles and historic sites.

Also, this national law defends inventorying and cataloguing procedures of built heritage as a mean to update and identify cultural property and, at the same time, as a measure of legal protection, avoiding its disappearance or degradation. However, it promotes the creation of these procedures only for classified assets, such as monuments or other constructions with national or public interest (a single person can request an inventory, if properly justified). The criteria for classification or inventorying are generic, being referred to issues like: "matrix character, aesthetic, technical or material intrinsic values of the assets...". Concerning intervention measures, this law (Portugal, 2001) establishes that studies and projects for conservation, modification, reintegration and restoration of classified built heritage must be authorized and followed by a competent body at the regional level. It also refers that interventions in monuments and historic ensembles and sites involving morphological, volumetric or chromatic changes, are not allowed. It should be noted that there is no regional legislation; this gap is not filled by the present interaction between the national laws and their support at municipal level. The actual national rehabilitation law (Portugal, 2012), and the national legal regime that concerns planning and building (Portugal, 2014b) regulate and support the interventions on built heritage at municipal level. The legal regime supports/defines different levels of intervention such as: construction works, reconstruction works, reconstruction works without preservation of the facades, expansion works, alteration works, works of conservation and demolition works, in agreement with the rehabilitation law (Portugal, 2012). It is also verified that the national rehabilitation law (Portugal, 2012) and the legal regime (Portugal, 2014b) establish identical intervention levels; however, these laws do not stress the importance of procedures of inventory and classification of existing buildings.

\section{Comparative analysis}

The procedures of gathering information on built heritage and the methods of inventorying and cataloguing vary considerably, depending on the criteria established by national laws. In Italy there are more uniform and multidisciplinary approaches on the classification of cultural built heritage in the entire territorial scales. These procedures are supported by unified criteria, allowing the creation of measures and levels of interventions that are uniform in all the Italian territorial scales, and are applied at the regional and municipal levels. In Spain, although the national law reflects itself in the region's laws, each region has its specified criteria, establishing its own approach. In this manner, these criteria are not uniform in the whole country, but each region adopts their own criteria to define classification of built heritage and the corresponding levels of intervention. In Portugal, the legislation concerned with patrimonial value is discrete and diffuse and doesn't promote the establishment of unified criteria to create databases, nor the classification and protection of current built heritage (Ornelas et al., 2014).

\subsubsection{Safety and housing conditions criteria}

The comparison of building codes and standards shows that the main criteria for intervention, apart from heritage protection, concern the guarantee of safety and housing conditions. Regarding safety, the codes establish different domains: structural safety (elements strength and stiffness); fire safety (material properties and means of escape); normal usage safety (conditions of slabs, stairs and functional areas). In terms of housing conditions, the codes impose criteria for compartments dimensions, conditions of hygiene, acoustic and hydrothermal comfort, lighting and ventilation, access to the building and inside the building and for the existence of certain facilities and equipment. This comparative study focuses on the application procedures of codes requirements involving old buildings.

\section{Italy}

In Italy, and at national level, the regulation concerned with structural safety (Italia, 2008) introduces different levels of intervention on built heritage: upgrading, improvement and localized repairs, depending on the patrimonial value and importance of the building, as well as on its state of conservation. Also, this regulation appeals to an exhaustive inventory of the constructive and material characteristics of the buildings before any intervention.

Concerning housing conditions, the minimum requirements (dimensions, ventilation, lighting and hygiene) are established at the municipal level [e.g. municipality of Verona (Italia, 2010)] and are associated with the characteristics of the local built heritage, promoting the balance between the preservation of building features and the establishment of housing conditions. In addition, there is a national law that establishes standards for controlling urban and building activity (Italia, 1985), 
which does not allow worsening the existing safety and housing conditions of built heritage.

Spain

In Spain, the building code(España, 2006) establishes criteria for structural safety, fire safety and housing conditions for new constructions. The application to existing buildings is done through the consideration of proportionality and flexibility criteria, allowing the decision to depend on the patrimonial value of the building and the technical and economic aspects of the intervention. In addition, the building code refers the criterion of not worsening the existing conditions of the buildings. It states that interventions on buildings should reach a minimum level of performance, but it introduces compensatory measures when it is not viable to achieve the overall level of performance required by the codes.

Finally, the building code allows the possibility of considering qualitative assessments, allowing alternative solutions reaching minimum safety criteria demands. It should be noted that the minimum housing condition requirements related to housing dimensions, ventilation, lighting and hygiene are established at the municipal level, according to the particularities of the constructive system and architecture of the region (España, 1997, España, 2012).

Portugal

In Portugal there are different building codes and standards related to safety and housing conditions. They are created at national level and applied at municipal level. The general building code (Portugal, 1951) imposes minimum housing conditions for compartment dimensions, ventilation, lighting and hygiene. The code requirements were originally established for new buildings and don't always fit the characteristics of old constructions.

Around two years ago a new law introduced in Portugal a special legal regime for urban rehabilitation (Portugal, 2014a). It introduces concessions regarding the compliance of some of the requirements defined in the national building code (Portugal, 1951) and other complementary regulations when intervening in existing buildings, namely those concerning acoustic and energy requirements, gas facilities and telecommunications infrastructures. It introduces the concept of flexibility, but in a "questionable" way, as its application must not be sustained by any previous inspection, diagnosis, or inventorying and cataloguing approach, or technical support. This regime reiterates the safety conditions of the Portuguese legal framework, a legal regime (Portugal, 2014b) that is mostly concerned with the control of building and urban planning interventions, through criteria such as not worsening the existing conditions.

Moreover, the actual rehabilitation law (Portugal, 2012) states the need to maintain the building facades, the number of floors, the architectonic and structural elements with particular value, as well as not to reduce the structural strength of the building, particularly its seismic safety.

\section{Comparative analysis}

The three countries include criteria of flexibility in their building regulations to allow the implementation of solutions that, although not entirely respecting code requirements, may better preserve the most valuable characteristics of the existing buildings. Italy and Spain sustain the application of these criteria by giving the technicians information about procedures/tools, based on technical knowledge and research, they should use. On the contrary, the special regime concerning building codes and regulations in Portugal introduces criteria of flexibility that are not based on any inventory and cataloguing process, or technical procedure that may help sustaining and justifying the interventions.

\subsection{General Remarks}

The overview of the building codes and legislation shows that the debate about the protection of cultural built heritage is moving forward, with different approaches and distinct criteria. In Italy, the national law concerned with the protection of built heritage has clear and uniform criteria to classify built heritage that are transversal to all the territorial scales. In Spain, there are different criteria for each region which allow establishing different classes of built heritage; the national law concerned with the protection of built heritage is only partially adopted at the regional level. However, in both countries the legislation points out that a comprehensive inventorying and cataloguing process is essential to classify and intervene in built heritage (Ornelas et al., 2014). Concerning Portugal, the legislation is more focused on inventorying and classifying monumental assets, discarding common built heritage.

Moreover, and concerning the application of safety and housing conditions, Italy and Spain introduce flexible criteria to match the national standards to the building characteristic of each region and community, sustaining the decisions on inventorying and cataloguing processes.

\section{EXPERTS VIEWS ON BUILDING CODES APPLICATION}

\subsection{Debate on intervention on built heritage}

During this study it was possible to collect different points of view from experts of governmental (national/ regional level), municipal (local level) and academic (national and regional level) institutions of Italy, Spain and Portugal, through interviews. 
In Italy, the interviews involved experts from governmental institutions of Siena, municipal institutions from Padua, Verona and Siena and academic institutions from Padua, Milan and Siena. In Spain, the experts come from governmental and municipal institutions of Madrid and academic institutions of Barcelona. In Portugal, experts were interviewed from governmental institutions of Lisbon and Porto, and Municipal and academic institutions of Porto.

The next paragraphs analyse, compare and confront the expert's views about the procedures of classification and intervention on built heritage, namely the importance of the codes in these processes.

\subsubsection{Classification criteria}

The experts in Italy, regardless of the entities they represent, recognize the importance and obligation of inventorying and cataloguing built heritage. They maintain that these processes should be established before any physical intervention, this being in agreement with the criteria inserted in the Italian codes and standards concerning the protection of built heritage. In particular, they highlight some issues: cultural built heritage and landscape should be classified as a whole; preservation should include cultural, economic and social values of historic ensembles; regional, provincial and municipal criteria and intervention plans should be linked; inventory and cataloguing processes must include structural, material, constructive and spatial characteristics of the buildings, their use and anomalies. Finally, they stress the need to create levels and measures of interventions associated to the patrimonial value of the buildings.

In Spain, the experts from governmental and municipal institutions underline the need for homogeneous criteria and measures to classify built heritage at regional and national level. Both, governmental and municipal experts, point out the need for cooperative planning and assessment forms to better classify built heritage. They reveal that cooperative interaction between technicians and citizens could increase the knowledge about the state of conservation of buildings and contribute to a more aware classification. On the other hand, academics underline that a holistic perspective on the assessment of built heritage is needed. They also reveal that an overall understanding of the building's construction features and of their functional requirements is essential to maintain its original characteristics.

In Portugal, the experts from the different institutions have different opinions concerning the criteria of building codes and standards related to protection of built heritage and its classification.
For instance, the governmental experts consider that the criteria for protection of built heritage are discretionary and diffuse. They emphasise the need to preserve urban areas. Also, they refer the need to establish assessment methodologies to identify patrimonial values of buildings within the actual law, as well as academics agree with this approach. On the contrary, the experts from municipal institutions are less critical about the code. They believe that classification included in actual municipal heritage plans is adequate.

\subsubsection{Safety and housing conditions criteria}

This subsection compares the experts' views concerning the application of safety and housing conditions criteria of building codes and standards on built heritage interventions.

In Italy, the experts, regardless of the entities they represent, agree with the standards stipulated at the municipal regulatory plans; they meet the characteristics of the built heritage and introduce flexibility criteria in its application. The experts say that the safety and housing conditions criteria included in these plans are strongly related to the cataloguing process. They maintain that old buildings should take into account new life styles and different residents' profile.

In Spain, experts of different institutions emphases that flexible criteria are necessary to support the application of safety and housing conditions, as expressed in the actual building code. Nevertheless, governmental experts are working on the improvement of these criteria and on the introduction of proportionality criteria to better adjust the actual safety and housing conditions code demands when dealing with old buildings. Academics also agree with this approach. They reveal the need to have an overall knowledge of the building's features and their functional requirements in order to reduce the intervention's environmental impact, namely through the maintenance of the building's materials. These specialists also underline the need to establish flexible requirements concerning housing conditions to better fit the different residents' profiles and needs. The municipal and governmental technicians agree on the need to develop technical inspections on built heritage, and to improve the application of safety and housing conditions criteria.

In Portugal, the experts' views, considering the application of safety and housing criteria on built heritage, are less convergent. Despite this, the views of governmental experts and academics converge. They state that the codes must introduce flexible criteria sustained by multidisciplinary views and adjusted to the old buildings characteristics. However, the academics go further in this discussion. They highlight the need for multidisciplinary 
assessments, involving exhaustive inspections on built heritage, and underline that only an integrated approach lead to sustained knowledge and to adequate interventions. Finally, these experts demand a more flexible, but sustained legislation regarding the rehabilitation of buildings. On the contrary, the municipal experts are less critical about the codes application criteria.

\subsection{Comparative analysis}

The analysis of the experts' views about the importance of the codes in the classification and intervention processes on built heritage shows that there are different views.

In Italy, the technicians of governmental, municipal and academic institutions converge on the importance of inventory and cataloguing before intervening on built heritage. Consistently, they point out that social and cultural issues are fundamental when intervening on built heritage, being aware of the duty to preserve and maintain built heritage.

In Spain, the experts of governmental institutions are aware of the difficulty to apply the technical criteria of the national building code. These specialists are seeking different approaches to better implement flexible criteria in the actual building codes, when dealing with old buildings. The academics views converge with those of the governmental experts, pointing out that the actual building code needs revision, especially in the redefinition of the housing conditions criteria. This idea comes up with the objective to obtain a more sustainable urban rehabilitation process, reducing its environmental impact and providing a social response that better meets the basic needs and expectations of the residents. On the other hand, the municipal experts are focused on the improvement of the cadastral maps in order to identify the patrimonial value of existing buildings, as well as on the improvement of technical inspections on built heritage in order to improve the application of safety and housing conditions criteria.

In Portugal, the experts' views about the application of actual building codes and standards vary. Although governmental and academic experts highlight the need to establish inventory and cataloguing processes, municipal experts do not question the lack of procedures to catalogue built heritage. Both governmental and academic experts reveal the need for more flexible criteria on the application of safety and housing conditions on built heritage. Municipal experts are typically concerned only with the application of the code criteria, expressing no critical opinion about it. Table 1 gives a brief overview about experts' views in Italy, Spain and Portugal.
Table 1. Experts view on the application of building codes criteria on built heritage.

\begin{tabular}{ll}
\hline Italy & $\begin{array}{l}\text { Experts converge on the need of inte- } \\
\text { grated approaches. } \\
\text { Joint efforts have been made to adjust } \\
\text { measures and level of interventions on } \\
\text { built heritage. }\end{array}$ \\
\hline Spain & Experts are moving forward to a more \\
& flexible application of the building \\
& codes criteria. \\
. Joint efforts have been made to create \\
level of \\
interventions on built heritage. \\
Portugal & $\begin{array}{l}\text { Experts do not converge yet. } \\
\text { Joint efforts have been made by } \\
\text { governmental and academic experts } \\
\text { to improve the assessment on built } \\
\text { heritage. }\end{array}$
\end{tabular}

\section{FINAL REMARKS: CRITICAL DIMENSIONS FOR AN ASSESSMENT METHODOLOGY}

This study does a systematic analysis to confront the existing criteria and measures of building codes and standards with the experts' views, considering classification and intervention on built heritage. This confrontation is applied to three different countries: Italy, Spain and Portugal.

The analysis shows that, despite the similarities between categories of assets and values, each country has different inventorying and cataloguing procedures. Also, the safety and housing conditions criteria are similar, although with different application measures on each country.

In Italy, the building codes and standards establish links between classes and measures and levels of intervention on assets at national, regional and municipal level. According to Italian experts, the Italian national codes and standards are properly designed and are adequate for the different scales. The experts highlight the assessment of built heritage at local level as an important support for establishing the technical standards and measures that better suit the characteristics of local built heritage.

In Spain, the building codes criteria and procedures related to the classification of built heritage are not uniform for the whole country. Each region sets different criteria and procedures, allowing different definitions of asset classes. Spanish experts from different institutions have a convergent view on the need for a more uniform definition and procedures for classifying built heritage. They recognize the importance of incorporating criteria of flexibility and proportionality within the code, 
especially when applying to existing buildings with patrimonial value. This way, Spanish experts emphasise the need for a careful assessment of built heritage and its characteristics, to ensure a proper and sustained code application.

In Portugal, the codes criteria and procedures are mainly established for classified assets. This approach is not consensual between experts. Academic and governmental experts reveal that a more sustained and knowledge based flexible approach should be implemented on codes and standards. They also recognize the need for a multidisciplinary assessment of built heritage in order to proper evaluate and take into consideration the regional and local characteristics.

This systematic analysis of codes highlights the importance to introduce general and homogenous criteria in the assessment and classification of built heritage, but also that this should be complemented by approaches and guidelines directed to its regional and local features in order to ensure interventions closer to the built heritage multidisciplinary characteristics (patrimonial, technical and social). Moreover, the experts underline that the implementation of building codes and regulations criteria have more success when supported by flexible and proportional criteria that take into account the built heritage and the intervention context.

Thus, this study offers new in puts for the improvement of codes and standards concerning intervention procedures on built heritage. In particular, it points out the need for an integrated assessment methodology, i.e. a more holistic knowledge with general criteria that allows evaluating the patrimonial, the technical, but also the social dimensions of built heritage. The evaluation of the residents' profile, perception and basic needs is pointed out by experts as being part of an all-inclusive assessment process of built heritage.

\section{ACKNOWLEDGMENTS}

The authors thank the Foundation for Science and Technology (FCT) for all the support, as lender of this Doctoral research through grant SFRH/ $\mathrm{BD} / 43755 / 2008$, as well as the governmental and public institutions in Italy, Spain and Portugal that supported the research with documentation and very useful exchange of views. The authors would also like to thank the anonymous referees for their valuable suggestions.

\section{REFERENCES}

Alonso, F. F. 2010. Rehabilitación integral de áreas urbanas y edificación residencial. El caso de Playa de Palma. In Congreso Regional Internacional Sustainable Building Madrid, 28-30 de Abril de 2010. Sb10mad: GBCe.

Arcas-Abella, J., Pagès-Ramon, A. \& Casals-Tres, M. 2011. El futuro del hábitat: repensando la habitabilidad desde la sostenibilidad. El caso español. Revista INVI. 26. 65-93.

Asensio, J. S. \& Martín, A. E. H. 2012. Los Catálagos de Protección: Herramientas urbanísticas de conservación del Património. In PATORREB 2012-4. ${ }^{\circ}$ Congreso de patología y rehabilitatción de edificios. Santiago de Compostela, Espanha, 12-14 de Abril de 2012. Colexio Oficial de Arquitectos de Galicia.

Casals-Tres, M., Arcas-Abella, J. \& Cuchí Burgos, A. 2013. Aproximación a una habitabilidad articulada desde la sostenibilidad: Raíces teóricas y caminos por andar. Revista INVI. 28. (77): 193-226.

España. 1985. Ley 16/1985, de 25 de junio, Ley del Património Histórico Español. BOE (155): 1-26 Madrid: Jefatura del Estado

España. 1997. Normas Urbanísticas del Plan General de Ordenación Urbana de Madrid (PGOUM 97) de 19 de Abril de 1997 BOCM (92): 6-148 Madrid: Ayuntamiento de Madrid.

España. 1998. Ley 10/1998, de 9 de julio, Ley do Patrimonio Histórico de la Comunidad de Madrid BOE (206): 29416-29434 Madrid: El Presidente de la Comunidad de Madrid, BOCM

España. 2006. Real Decreto 314/2006, de 17 de marzo, por el que se aprueba el Código Técnico de la Edificación. Ultima modificacíón conforme a la Ley 8/2013, de 26 de junio, de rehabilitación, regeneración y renovación urbanas BOE (74): 11816-11831 Madrid: Ministerio de Vivenda.

España. 2011a. Decreto de 31 de marzo de 2011, Protocolo de Condiciones de Protección del Patrimonio Histórico, Artístico y Cultural BOAM (6.421): 15-52 Madrid: Presidente del Consejo Rector de la Agencia de Gestión de Licencias de Actividades

España. 2011b. Ordenanza de Conservación, Rehabilitación y Estado Ruinoso de las Edificaciones de 27 de diciembre de 2011 BOCM (6580): 1-26 Madrid: Ayuntamiento de Madrid.

España. 2012. Decret 141/2012, sobre condicions mínimes d'habitabilitat dels habitatges i la cèdula d'habitabilitat, 2 de Noviembre DOGC (6245): 53432-53452 Catalunya: Departament de Territori i Sostenibilitat.

España. 2013. Ley 8/2013: Ley de Rehabilitación, regeneración y renovación urbanas, de 27 de junio BOE (153): 1-28 Madrid: Jefatura del Estado

Fianchini, M. \& Fontana, C. 2010. Integrated BPE: a proposal to balance conservation and transformation in the sustainable reuse/reabilitation project of existing buildings. In Sustainable Building Conference. Madrid, Espanha, 28-30 de Abril de 2010. Sb10mad: GBCe.

García-Martinez, A., Llatas, C., Llatas, O. \& Johansson, E. 2010. The Architect's Role in Eco-Efficiency Managment in Building Works Within the Framework of Spanish Legislation. In Sustainable Building Conference. Madrid, Espanha, 28-30 de Abril de 2010. Sb10mad: GBCe.

Italia. 1978. Legge 5 agosto $1978, n .^{\circ} 457$, Norme per l'edilizia residenziale Gazzetta Ufficiale (231): 1-32 Roma: Il Presidente della Repubblica. 
Italia. 1985. Legge 28 febbraio 1985, n. ${ }^{\circ} 47$, Norme in materia di controllo dell'attività urbanistico-edilizia. Sanzioni, amministrative e penali Gazzetta UfficialeSupplemento Ordinario (53): 1-12 Roma: La Camera dei deputati ed il Senato della Repubblica.

Italia. 2004. Decreto Legislativo 22 gennaio 2004, n. ${ }^{\circ}$ 42, Codice dei beni culturali e del paesaggio, ai sensi dell'articolo 10 della legge 6 luglio 2002, n. ${ }^{\circ} 137$ Gazzetta Ufficiale-Supplemento Ordinario n. ${ }^{\circ} 28$ (45): 1-78 Roma: Consiglio dei Ministri del Beni Culturali.

Italia. 2008. Decreto Ministeriale 14 gennaio 2008, Istruzioni per l'applicazione delle "Nuove norme tecniche per le costruzioni Gazzetta Ufficiale-Serie generale (47): 1-654 Roma: Ministero delle Infrastrutture e dei Trasporti.

Italia. 2010. Regolamento d'igiene di Verona Deliberazione del Consiglio Comunale (92 ): 1-102 Verona: Comuna di Verona.

Italia. 2012. Piano Regolatore Generale - Norme Tecniche di Attuazione Aggiornato alla 22 gennaio 2012 Padova: Comune di Padova, Settore Piannificazione Urbanistica.

Ornelas, C., Guedes, J. \& Breda-Vázquez, I. 2014. The Minimum Intervention in Built Heritage: comparing the potencial role of codes for conservation. In 9th International Masonry Conference Guimarães, Portugal, 7-9th July, 2014. Minho University: IMC.

Portugal. 1951. Decreto-lei n. ${ }^{\circ} 38382,7$ de Agosto de 1951, Regulamento Geral das Edificações Urbanas Diário do Governo, I Série (166): 1-15 Lisboa: Ministério das Obras Públicas.
Portugal. 2001. Lei n. ${ }^{\circ} 107 / 2001$, de 8 de Setembro, Estabelece as bases da política e do regime de protecção e valorização do património cultural, Diário da República, I Série (209): 5808-5829 Lisboa: Assembleia da República.

Portugal. 2012. Lei n. ${ }^{\circ}$ 32/2012, de 14 de agosto, Procede à primeira alteração ao Decreto-Lei n. ${ }^{\circ} 307 / 2009$, de 23 de Outubro, que estabelece o regime jurídico da reabilitação urbana, e à 54. ${ }^{a}$ alteração ao Código Civil, aprovando medidas destinadas a agilizar e a dinamizar a reabilitação urbana Diário da República, I Série (157): 4452-4483 Lisboa: Assembleia da República.

Portugal. 2014a. Decreto-lei $n .^{\circ} 53 / 2014$, de 8 de Abril, Regime de Excecional de Reabilitação Urbana Diário da República, I Série (69): 2337-2340 Lisboa: Ministério do Ambiente, Ordenamento do Território e Enérgia.

Portugal. 2014b. Decreto-Lei n. ${ }^{\circ}$ 136/2014, de 9 de setembro, que procede à alteração do Decreto-Lei n. ${ }^{\circ} 555 / 99$, de 16 de Dezembro, Regime Jurídico da Urbanização e da Edificação Diário da República, I Série (173 ): 4809-4860 Lisboa: Ministério do Ambiente, Ordenamento do Território e Energia.

Rumor, M. \& Gonzato, R. 1989. Computer Aided Planning. The experience of the city of Padova. Lisboa, Portugal: António Morais Arnaud.

Tenorio Rios, J. A., Sorribes Gil, M. \& Queipo De Llano, J. 2012. Niveles de Intervención en Rehabilitación. In PATORREB 2012-4. ${ }^{\circ}$ Congreso de patología y rehabilitación de edificios. Santiago de Compostela, Espanha, 12-14 de Abril de 2012. Colexio Oficial de Arquitectos de Galicia. 